\author{
Arvydas Paskevicius, \\ Ph.D., Professor, Head of the Department of Finance, \\ Faculty of Economics and Business Administration, Vilnius University, \\ Vilnius, Lithuania
}

Greta Keliuotyte-Staniuleniene,

Ph.D., Assistant Professor, Department of Finance,

Faculty of Economics and Business Administration, Vilnius University,

Vilnius, Lithuania

\title{
THE EVALUATION OF THE IMPACT OF FINANCIAL TECHNOLOGIES INNOVATIONS ON CEECS CAPITAL MARKETS
}

\begin{abstract}
Although there is a number of researchers studying innovations in general specifically pointing out the risky nature of financial innovations, and the necessity to study their impact the empiric studies describing the effect of the innovations in financial technologies upon capital markets are scarce. There is no credible evidence leading to an unambiguous conclusion as to the impact of innovation in financial technologies upon the development of capital markets in Central and East European countries (CEECs). Thus, the main scientific problem of this article is the lack of reliable quantitative evidence of the impact of innovations in financial technologies on capital market development in CEECs. According to that, the aim of this article is to assess the impact of the financial technologies innovations upon the capital markets of the CEECs on the basis of the most recent available data (2006-2017). The study methods employed by the authors included an analysis of the relevant scientific literature, comparative dynamic analysis, panel data models (constant, fixed and random effects) and other statistical methods. As a result, the panel model of the impact upon the capital markets in CEECs is developed based on the analysis of the data from 9 Central and Eastern European countries for a period of 12 years (2006-2017). The model suggested by the authors explains almost four fifths of the changes in the capital market expressed in the capitalisation indicator. The panel models of constant, fix and variable effects is an evidence of a negative statistically significant impact of the summary innovation index reflecting the level and the scope of financial technologies upon the development of capital markets in the Central European States when the other selected macroeconomic variables remain in control. The panel model of development of capital markets also showed that a statistically significant positive impact upon the capital market development in CEECs was produced by forecasted GDP growth, inflation and capital investment factors (variables). On the other hand, foreign direct investment, unemployment, interest rate, public debt, government budget deficit do not have a statistically significant impact upon the development of capital markets in the selected CEECs. The model constructed by the author is characterised by fairly high reliability and determination indicators, therefore, may be used for the purpose of a further assessment and projecting of the impact of financial technologies and other actions upon the development of the capital markets.
\end{abstract}

Keywords: innovation, financial technologies, capital market development, capitalisation, impact assessment.

Introduction. The continuously emerging innovations, including financial technologies innovations produce an overall effect upon the qualitative and quantitative parameters of economic growth. New products and services created by means of financial technologies innovations cause and shape the development of financial markets. Financial technologies innovations are used as a means to compete with conventional financial products. In the course of the past decade the volumes of investment in this service sector have been drastically increasing. Financial technologies innovations have been increasingly often referred to as a means to have access to new credit sources, which inevitably causes an impact upon capital markets. 
Although there is a number of researchers studying innovations in general $[8 ; 25]$ specifically pointing out the risky nature of financial innovations, and the necessity to study their impact [22] the empiric studies describing the effect of the innovations in financial technologies upon capital markets are scarce $[6 ; 20$; $21,23]$. There is no credible evidence leading to an unambiguous conclusion as to the impact of innovation in financial technologies upon the development of capital markets in Central and East European countries (CEECs).

Thus, the main scientific problem of this article is the lack of reliable quantitative evidence of the impact of innovations in financial technologies on capital market development in CEECs. According to that, the aim of this article is to assess the impact of the financial technologies innovations upon the capital markets of the CEECs on the basis of the most recent available data (2006-2017).

Literature review. Innovations in financial technologies: concept and evaluation possibilities. Innovation in financial technologies is an independent economic category expressing the relevant relations by developing, implementing and using innovations in the financial sector of an economy [29]. Innovations in financial technologies reinforce the sustainability of institutions. Innovations in financial technologies, i.e. new, previously not used financial instruments, methods, technologies and organisational forms - have a considerable impact upon economic units, countries and the global economy [28]. In other words, those are the technologies modifying and simplifying financial processes [19]. Overall, innovations in financial technologies may be classified as the financial system innovations, process innovations and product innovations [18]. Some other authors [6; 13; 15] distinguished complimentary innovations (development of new structures to the existing products), breakthrough innovations (exercising significant effect upon the overall market level), and disruptive innovations (disruption of the current market model, change in strategy).

A quantitative assessment of the development of innovations in financial technologies remains an equally challenging task. Scientific literature uses a wide variety of indicators as measures of innovations, among them being profit or risk, net profit and innovations expenses indicator [3; 4; 23], innovations payback time [16], innovation activity success rate [25], etc. On the other hand, none of the above indicators ensures a comprehensive assessment of the level or quality of innovations in financial technologies. In recent years for the purpose of assessment of the development of innovations in financial technologies more and more researchers and institutions use aggregated indicators computed on the basis of a multicriteria assessment method, i.e. such indices as global innovation index [38], [39], technology achievement index [37], index of technological progress [36], knowledge economy index [32; 34], fintech index [35], summary innovation index [11, 26].

In respect of the study carried out for the purpose of the present paper, most of such indices are either overly bread, i.e. aggregating an excessive number of different type indicators (e.g. innovative capacity index, global innovation index), or they are too removed from the area being studied (oriented towards purely technological and human aspects) (e.g. technology achievement index, knowledge economy index, index of technological progress). Certain indices (such as fintech index) could be used for the assessment of the impact of financial technologies for the development of capital markets, however, they have a very short data track, since 2016 only. Meanwhile, the summary innovation index (SII) has been computed by the European Commission since 2000, comprises a number of key aspects covered by the study, such as development of information society, the liberal nature of markets, development of telecommunications and computer technology companies, such as Fintech companies and development of business-friendly conditions. The index has been computed for each Member State of the European Union and ranges in the interval from a zero (lowest innovations level) to 1 (highest level of innovations).

Assessment and the key factors in the development of the capital market. An analysis of the factors mostly affecting the development of the capital market, and the impact of innovations in financial technologies upon the development, requires a that the quantitative measure of capital market 
development is defined. A capital market development indicator most often used in scientific literature is a ratio between market capitalisation and the GDP [2; 5; 30]. The indicator is considered highly advantageous, as finding the key accurate information about the market capitalisation in different countires. On the other hand, the measure is more appropriate for the countries having similar economic characteristics [2].

The analysis of the research literature $[2 ; 31 ; 33 ; 36]$ led to a generalisation of the key capital market actions, and the relevant indicators reflecting them: GDP growth rate, inflation, interest rate level; currency rate fluctuations; budget deficit; public debt, unemployment level, foreign direct investment and GDP ratio, capital investment and GDP ratio, etc..

Overview of recent researches. It is necessary to note that scientific papers analysing the impact of innovations in financial technologies upon the development of capital markets are not numerous. The analysis of the relevant research literature [26; 29] allowed identifying the following manifestations of positive effect of financial technologies upon the development of capital markets: rapid dissemination of information and reduction in information asymmetry, simplified access to financial markets and resources, increase in the volumes of financial assets at the disposal of investors, acceleration of financial flows and operations, reduction in operating expenses and increase in the flexibility of capital structure. Undoubtedly, it should be particularly noted that an uncontrolled development of financial technologies is related to certain risks and threats for the entire financial system, and, in the presence of specific conditions may threaten the macroeconomic stability.

The methods most frequently used for the assessment of the impact produced by capital market factors include a correlation-regression analysis, and the application of panel data models $[1 ; 9]$.

In summary it could be concluded that until now the key attention of the research in the area was focused upon the analysis of the factors shaping the capital market development level and the further development, leaving the impact of financial innovations upon the capital markets in the CEECs handled only superficially. On the other hand, up until now there is no single agreed methodology to assess the impact in quantitative terms. In this background it is necessary to construct a model of the assessment of innovations in financial technologies, and apply it in practice.

Research methodology. Recovering from the global financial crisis of 2007, ensuring the stability of the financial system became the primary goal of the major banks in the world and other financial institutions: that became the principal task of the efforts exercised in avoiding the enormous financial losses caused by the instability of the financial system. On the other hand, the complexity of innovations and the structure of the financial system are the key characteristics of the modern financial system. Such characteristics allow an efficient distribution of financial resources and management of related risks, however, at the same time, this increases the sensitivity of the financial system towards systemic shocks. Considering the trends of the past years it is necessary to quantitatively assess the impact of innovations in financial technologies upon the financial system. Although it is fairly obvious that the development of financial technologies does affect both financial institutions and the financial markets, the objective of the study covered by the present paper is limited to an analysis of the impact of innovations in financial technologies upon capital markets.

Considering that the impact of innovations in financial technologies upon the capital markets of the CEECs, the study concerned includes 9 selected post-soviet states from the Central and Eastern Europe (members of the European Union) (Lithuania, Latvia, Estonia, Czech Republic, Slovakia, Bulgaria, Romania, Poland and Hungary ). Initially the scope of the study was defined as including all the Member States of the EU, however, having considered certain vital aspects (certain data absolutely necessary for the study are not publicly available, diversified characteristics of the countries, significant differences in the capital markets of individual countries) the object was narrowed to the block of the countries listed above (new members of the European Union, characterised by a more or less similar geopolitical situation 
and development of financial structure).

The period being considered a period of 2006-2017. The selection of the period is based on the economic, methodological and practical considerations. On the one hand, according to the selected methodology the data line is required to cover the periods of stability of capital markets, and growth as well as instability (crisis period). On the other hand, for the purpose of the study covered by the present paper the period was selected having considered the possibilities of accessibility and comparability of the data.

At first, a comparative dynamic analysis of the capital markets and their key factors in CEECs is conducted. The market capitalisation and the GDP ratio were selected as an estimate for the quantitative capital market development (an independent variable of the study). Capitalisation as part of the GDP is one of the main and most frequently used indicators to assess the level of development of financial markets; furthermore, the information on the values of the indicators is fairly timely and readily available in all countries being studied).

Given that the number of observations for the purpose of the study presented in the present paper ( 9 countries and a period of 12 years) is not sufficient for studying the dynamics of the capital market development (capitalisation) in terms of time (time series models), or the course of development between the countries (cross-section models), there is a growing need to search for other possibilities to analyse the available data. Panel or cross-section time series data is a set of data demonstrating the change in time of specific objects of a cross-section [27]. Ordinarily panel models allow covering larger volumes of data, than studying cross and time series models, and enable studying the variation both within the group (variation over time), as well as the variations between the groups (a change in respect of other items being studied).

It is particularly the possibility to use for a study a larger number of observations, larger number of degrees of freedom, as well as a lower risk of multicollinearity, and a more efficient identification of the interrelation between an independent variable and dependent variables that largely expands the possibilities of statistical analysis and enhances the reliability of the results [14]. For this reason panel data models were selected to be used for the analysis of the factors in the capital market development, and for the quantitative assessment of the impact. Thus, an aggregation of the observations of all selected countries into a single group (9 States* and 12 years) produces a balanced panel of 108 observations, which allows obtaining reliable statistical analysis results. For that purpose, an invariant constant panel model (1) is created as a reference point.

$$
\mathrm{Y}_{\mathrm{it}}=\alpha+\beta \mathrm{X}_{\mathrm{it}}+\mathrm{u}_{\mathrm{it}}
$$

where: $Y_{i t}$ - dependent variable; $X_{i t}$ - independent variable; $\alpha$ - constant; $\beta$ - coefficient; $u_{i t}$ - error; $\mathrm{i}=1, \mathrm{~N}$ (number of countries); $\mathrm{t}=1, \mathrm{~T}$ (number of periods).

The invariable constant model is constructed based on an assumption that all objects of the crosssection are homogeneous, i.e. the a constant is identical for all objects observed. In other words, it is assumed that in respect of the capital markets and its development factors all countries are not materially different.

Further it is assumed that with respect to capital markets the selected countries are not homogeneous, i.e., their a constants are different; further a fixed effect model is constructed in which each country is assigned a different constant (2).

$$
\mathrm{Y}_{\mathrm{it}}=\alpha_{\mathrm{i}}+\beta \mathrm{X}_{\mathrm{it}}+\mathrm{u}_{\mathrm{it}}
$$

In order to verify whether it is reasonable to apply a fixed effect model (the countries are not 
homogeneous), or rather it is sufficient to use an invariable constant model (the countries are homogeneous) a F-test is used:

1. $H_{0}: \alpha_{1}=\alpha_{2}=\cdots=\alpha_{n}$ (the constants of all countries are equal);

2. $H_{a}: \alpha_{s} \neq \alpha_{j}$ (the constant of at least one country is not equal to the constants of the other countries).

The estimated $\mathrm{F}$ test value (according 3 ) is reconciled with the critical value of the $\mathrm{F}$ test $(\mathrm{N}-1$ and NT-N-K degrees of freedom). In case the estimated $\mathrm{F}$ test value is higher than the $\mathrm{F}$ test critical value, the zero hypothesis is rejected and a fixed effect model is used for constructing the model.

$$
F=\frac{\left.\left(R_{F E}^{2}-R_{C C}^{2}\right) /(N-1)\right)}{\left(1-R_{F E}^{2}\right) /(N T-N-k)} \rightarrow F(N-1, N T-N-k)
$$

where: $R_{F E}^{2}$ - determination coefficient of model with fixed effects; $R_{C C}^{2}$ - determination coefficient of model with invariable constant; $\mathrm{N}$ - number of countries selected; $\mathrm{K}$ - number of independent variables; $\mathrm{T}$ - number of periods.

The next step is the formation of the capital market development model with random effects. In this case it is assumed that the countries are not homogeneous, however, differently from the case of fixed effects, their differences change over the period being considered, i.e. they are not of constant, but rather of a random nature $\left(\alpha_{i}=\alpha+v_{i}\right)$. In this case the model constant is identical for all selected countries, however, the errors are different (4).

$$
\mathrm{Y}_{i t}=\alpha_{\mathrm{i}}+\beta \mathrm{X}_{\mathrm{it}}+\left(\mathrm{ui}_{\mathrm{i}}+\mathrm{v}_{\mathrm{i}}\right)
$$

where: $\mathrm{v}_{\mathrm{i}}$ - random variable.

A Hausman test (5) is applied in order to determine which of the models - the fixed effect or random effect model is more suitable in a specific case.

$$
H=\left(\widehat{\beta}^{\mathrm{fe}}-\widehat{\beta}^{\mathrm{ae}}\right)^{\prime}\left[\operatorname{var}\left(\widehat{\beta}^{\mathrm{fe}}\right)-\operatorname{var}\left(\widehat{\beta}^{\mathrm{ae}}\right)\right]^{-1}\left(\widehat{\beta}^{\mathrm{fe}}-\widehat{\beta}^{\mathrm{ae}}\right)
$$

where: $\widehat{\beta}^{\text {fe }}-$ value of parameter for model with fixed effects; $\widehat{\beta}^{\text {ae }}-$ value of parameter for model with random effects.

In case an estimated value of the Hausman test is larger than the critical chi-square test value with $\mathrm{k}$ degrees of freedom $\left(\chi^{2}(\mathrm{k})\right)$, then the zero hypothesis is rejected, and a fixed effect model is chosen to be used instead.

Then the model coefficients are assessed, i.e. t- statistics and the probabilities $p$. In case the variable does not constitute a statistically significant section of the model, such factor is removed from the model. Finally, the determination of the constructed model is assessed on the basis of the $R^{2}, R^{2}$ adjusted, DurbinWatson and F-statistics value. The methods described above is used to carry out a panel assessment of the capital market development, with a view to establishing the indicators that would provide an explanation of the changes in the capitalisation in the group of CEECs concerned in 2006-2017. On the basis of the analysis of the scientific literature $[2 ; 26 ; 30 ; 31 ; 33$; etc.], and considering the possibilities to collect the data, the selected indicators potentially affecting the development of the capital market were included in the model as explanatory variables (Table 1). 
Table 1 - Selected independent variables - possible determinants of capital market development (developed by the authors)

\begin{tabular}{|l|l|}
\hline \multicolumn{1}{|c|}{ Variable } & \multicolumn{1}{c|}{ Source } \\
\hline GDP growth & Eurostat \\
\hline Inflation rate & Eurostat \\
\hline Foreign direct investments/GDP & European Commission \\
\hline Unemployment & Eurostat \\
\hline Interest rate & Eurostat \\
\hline Capital investment/GDP & Eurostat \\
\hline Government budget deficit & Eurostat \\
\hline Public debt & Eurostat \\
\hline Summary Innovation Index & European Commission \\
\hline
\end{tabular}

As regards the selection of independent variables, it is necessary to note that the importance of innovations in financial technologies and its impact may be assessed by referring to a range of methods discussed in the earlier section of the paper. On the other hand, one of the most important indicators reflecting the processes of the financial technologies innovations sector, and the situation referring to their manifestation in different countries is the summary innovation index [11]. Specifically, due to its accessibility and the sufficient long data series (the European Commission produces annual innovation overviews that presents the summary innovation index values in individual countries) the index was selected to assess the development of innovations in financial technologies.

After modelling and evaluating all possible combinations of independent variables, the most suitable model is selected having considered the results of the test of its appropriateness, reliability and determination. The results of the calculations performed according to the logical series as described above are presented in the following section of the article.

Research results. A comparative dynamic analysis of the development of the capital markets of CEECs. The development of capital markets in CEECs in 2006-2017 is being assessed using the market capitalisation indicator (percentage of GDP); the indicator in the scientific literature is referred as principal, and is included in the constructed model as a dependent variable. In Figure 1 countries from selected panel is sorted by the level of capital market development. The limit values of market capitalisation were calculated for the sake of comparison (Table 2).

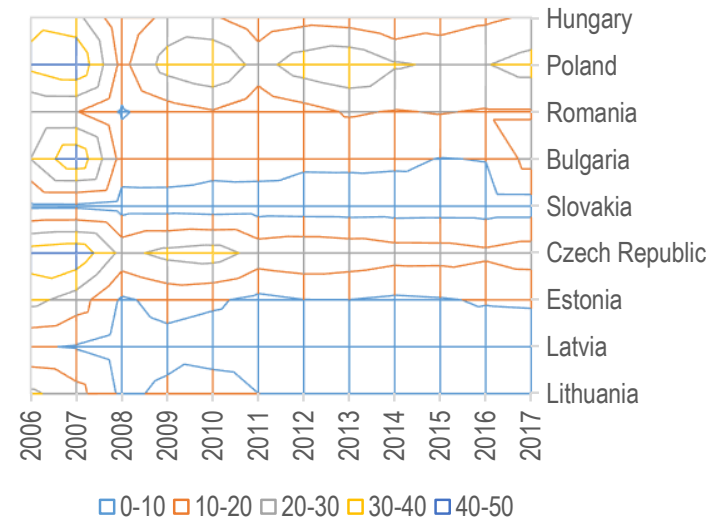

Figure 1 - Market capitalization/GDP in CEECs, 2006-2017, \% (developed by the authors on the basis of [11] data) 
Table 2 - Limit values of market capitalisation/GDP in CEECs, 2006-2017 (developed by the authors on the basis of [7] data)

\begin{tabular}{|l|l|l|l|l|}
\hline & Average & Min & Max & $\begin{array}{l}\text { St. } \\
\text { deviation }\end{array}$ \\
\hline Lithuania & 12.86 & 7.98 & 32.10 & 7.51 \\
\hline Latvia & 5.51 & 3.22 & 11.00 & 2.40 \\
\hline Estonia & 13.20 & 7.45 & 33.22 & 7.83 \\
\hline Czech Republic & 30.35 & 21.88 & 47.96 & 8.48 \\
\hline Slovakia & 5.70 & 4.60 & 8.39 & 1.27 \\
\hline Bulgaria & 18.34 & 9.70 & 48.40 & 11.17 \\
\hline Romania & 17.74 & 8.72 & 20.99 & 3.78 \\
\hline Poland & 33.97 & 17.01 & 49.30 & 8.45 \\
\hline Hungary & 19.55 & 10.42 & 36.53 & 8.18 \\
\hline
\end{tabular}

The lowest value of the indicator is recorded in Latvia (3.22 per cent), and highest value is recorded in Poland (49.30 per cent). The mean of capitalisation of the countries compromising the group during the period of 2006-2017 was about 17 per cent. The indicators of Lithuania, Latvia, Estonia and Slovakia are below the regional mean, the indicators in Bulgaria, Romania and Hungary are similar to the regional mean, and the remaining 2 countries (Czech Republic and Poland) are above the average (it should be noted, that despite the fact that market capitalisation/GDP average value in Bulgaria is relatively high, this is resulted by extraordinary high value in year 2007, in other words, high standard deviation). On the other hand, average EU capitalization in year 2006-2017 was around 45 per cent. Thus, in comparison with EU, the capital markets of selected CEECs are not yet sufficiently developed.

An assessment of the dynamics of the summary innovation index in the selected countries (Figure 2) showed that in terms of this indicator most CEECs demonstrate growth during the period analysed, but nevertheless, still lag behind the EU average (0,51 in year 2017 [10]).

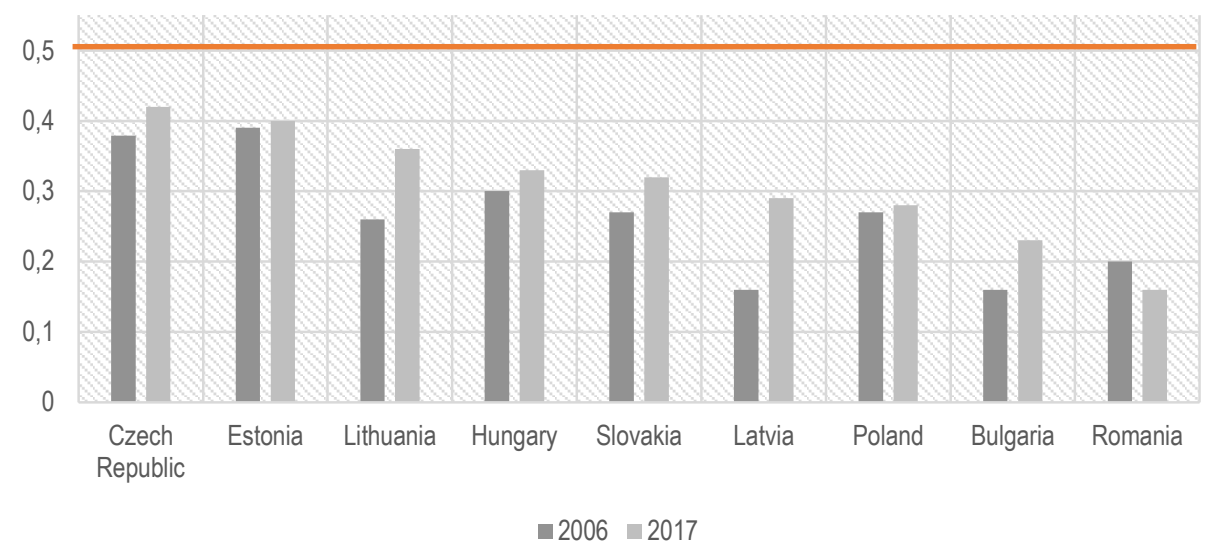

Figure 2 - Summary innovation index in CEECs, 2006-2017 (developed by the authors on the basis of $[10 ; 11]$ data)

Czech Republic, Estonia, Hungary, Latvia, Lithuania, Poland, Slovakia can be called moderate innovators, while Bulgaria and Romania are modest innovators with performance well below that of the EU average [10]. 

Capital Markets

Another aspect deserving in-depth consideration is the changes in the capital market development factors (indicators). In view of the limitations of the study and taking into account the main goal of this paper, only the innovation in financial technologies factor (independent variable - summary innovation index) was selected for the comparative analysis. Comparative analysis revealed that some of selected countries demonstrate relatively high results both in capital market development and innovations in financial technologies (i.e. Czech Republic, Hungary), some of them demonstrate relatively high level of financial innovations, but low capital market development (i. e., Lithuania, Estonia), and some - have relatively well developed capital markets, but are modest innovators (i.e. Bulgaria, Romania, Poland). The key differences between the CEECs were identified through a comparative analysis of the independent and dependent variables selected for the purpose of the study.

The dynamic analysis of the capital market development and innovations in financial technologies indicators lead to a conclusion that the area has not reached its full development, however, demonstrates significant potential and an impact upon the performance of such financial markets as capital markets.

Panel data models of the capital market factors of CEECs. A panel model of capital market factors is constructed with a view to establishing the impact of the independent variables upon the development of the capital markets. The model is instrumental in statistically assessing the direction and the strength of the impact, and most importantly, in determining whether or not innovations in financial technologies have a significant impact upon the development of the capital markets in CEECs.

The panel models of capital market factors are constructed on the basis of the study methodology as described above; such models allow determining whether the dynamics in the capitalisation of the capital market in CEECs in 2006-2017, inter alia, may be explained by the dynamics of the summary innovation index that includes the financial technologies innovations. These models also estimate in quantitative terms the impact of innovations in financial technologies upon capital markets.

The panel data (108 observations) was used to construct the invariable constant, fixed effect and dynamic effect models whose appropriateness is assessed on the basis of the methodology described above. An assessment of all the meaningful combinations of the selected 8 variables (Table 1) allowed a conclusion that the dynamics of the capitalisation of capital markets is best explained by this model - the four meaningful independent variables (Table 3).

Table 3 - Panel model of capital market development factors (developed by the authors)

\begin{tabular}{|l|l|l|l|}
\hline & Coefficient & t-statistics & P \\
\hline Constant & 20.204 & 2.594 & 0.011 \\
\hline $\mathrm{X}_{1}:$ GDP growth (1) & 0.654 & 3.622 & 0.001 \\
\hline $\mathrm{X}_{2}:$ Inflation & 0.386 & 1.485 & 0.143 \\
\hline $\mathrm{X}_{3}:$ Capital investment/GDP & 0.626 & 3.065 & 0.003 \\
\hline $\begin{array}{l}\mathrm{X}_{4}: \text { Summary innovation index } \\
\text { (log) }\end{array}$ & -15.82 & -2.755 & 0.007 \\
\hline Observations & 108 & \\
\hline F test & $\mathrm{F}(5,85)=49,94$ (null hypothesis rejected) \\
\hline Hausman test & $\mathrm{X}^{2}(4)=4,09$ (null hypothesis cannot be rejected) \\
\hline $\mathbf{R}^{2}$ & 0,77 & \\
\hline $\mathbf{R}^{2}$ Adj. & 0,74 & \\
\hline F-stat & 23,23 & \\
\hline DW & 1,73 & \\
\hline
\end{tabular}

Having constructed a panel model with fixed effects a $F$ text was carried out, as a result of which the zero hypothesis that the fixed effects were redundant (estimated $F=49,94, p=0,00$ ) was rejected; that testifies the presence of constant differences between the capital markets of the countries covered by the 
present study, i.e. since in the case of each country the model constant is different, it may be concluded that irrespective of the impact of the independent variables included in the model, the CEECs are characterised by a different capital markets development level.

The same variables served as a basis to construct a panel model with dynamic effect and carry out a Hausman test (comparing the estimates of the fixed effects and the dynamic effects). The $X^{2}$ was estimated as equal to 4.09, which did not allow rejecting the zero hypothesis, claiming that the estimates of the random effect method are reconciled. It follows that in the case being examined the construction of the model based on random effect method is more appropriate, which indicates that the differences between the countries examined (their capital markets) in the study are more of a random (varying in time), rather than of constant nature. On that basis a conclusion may be drawn up more on the different market reaction to random exogenous shocks rather than the difference of development and the structure of financial markets.

At last, the model is checked for its determination and the reliability. The determination coefficient value (0.77) showed that the movement of the independent variables explains nearly 80 per cent or $4 / 5$ of the fluctuations in the capitalisation of the CEECs. The F-statistics value confirmed that the structure of the produced model is suitable, i.e. that the model is statistically significant (there is at least one factor that affects the dependent variable). A Durbin-Watson test was completed for the purpose of establishing the autocorrelation of errors (estimated DW $=1.73$ ) showed an absence of the autocorrelation between the errors of the model. All the variables included in the model are characterised by sufficient materiality at a confidence level of 10 per cent (except inflation that is accepted at 15 per cent confidence level), and the mathematical symbols of the coefficients are consistent with the economic logics. The developed model may be interpreted as follows:

- when the forecasted rate of economic growth increases by 1 percentage point, the market capitalisation would increase by about 0.65 percentage points, when the values of other variables remain unchanged, i.e. expected economic growth supports the development of the capital market, and is conducive to attracting more companies issuers and investors;

- in case inflation increases by one percentage point, the market capitalization would increase by 0.386 percentage points, i. e. decreasing real borrowing costs encourages companies to borrow in capital markets, while lower real interest rates for bank deposits encourage investors to search for higher return opportunities in capital markets;

- when capital investment (as a share of GDP) increases by 1 percentage point, the market capitalisation would increase by about 0.626 percentage points, when the values of other variables remain unchanged, which shows an increasing need to attract funds from capital markets;

- in case the summary innovation index increases by one percentage point, the market capitalization would decrease 0.158 percentage point when the values of the other variables remain unchanged, i. e. growing innovations in financial technologies can negatively affect capital markets by creating new competition to traditional securities exchanges etc.

The model of the capital market development defines the dependence of the dynamics in the capital market capitalisation upon the development of innovations in financial technologies and other variables. Thus, it may be concluded that the model constructed for the purpose of the present study clearly demonstrated a statistically significant impact of innovations in financial technologies (even having included other controlling independent variables). As evident from the data provided earlier (Table 3), the model is suitable for purpose and statistically reliable, and explains about 77 per cent of the market capitalisation dispersion. The capital market factor model may be expressed according to Formula 6 :

$$
Y_{i}=20,204+0,654 x_{1}+0,383 x_{2}+0,626 x_{3}-15,82 \log \left(x_{4}\right)+\left(u i_{i}+v_{i}^{*}\right)
$$
where: $v_{i}^{*}-$ random variable for country $i$. 
The interpretation of the index's values leads to conclusions on the existence of the impact of innovations in financial technologies and other independent variables upon the development of the capital markets, the nature and the strength of such impact.

Conclusions. As shown in scientific literature innovations in financial technologies, i.e. new, previously not used financial instruments, methods, technologies and organisational forms - have a considerable impact upon economic units, countries and the global economy.

The panel model of the impact upon the capital markets in CEECs is developed based on the analysis of the data from 9 Central and Eastern European countries for a period of 12 years (2006-2017). The model suggested by the authors explains almost four fifths of the changes in the capital market expressed in the capitalisation indicator.

The panel models of the invariable constant, fix and variable effects is an evidence of a statistically significant negative impact of the summary innovation index reflecting the level and the scope of financial technologies upon the development of capital markets in the Central European States when the other selected macroeconomic variables remain in control. The panel model of development of capital markets also showed that a statistically significant positive impact upon the capital market development in CEECs was produced by forecasted GDP growth, inflation and capital investment factors (variables).

On the other hand, foreign direct investment, unemployment, interest rate, public debt, government budget deficit do not have a statistically significant impact upon the development of capital markets in the selected CEECs.

The characteristics of the model (random effects) show the existence of the random differences between the developments of the capital market related the occurrence of random shocks and market reaction. The model of the factors of the capital market development constructed by the author defines the dependence of the market capitalisation indicator dynamics upon financial technologies and other variables, and is characterised by fairly high reliability and determination indicators, therefore, may be used for the purpose of a further assessment and projecting of the impact of financial technologies and other actions upon the development of the capital markets.

Suggestions for future researches. It should be noted that the model offered is based on the analysis of data of 9 states of Central and Eastern Europe in the period of 12 years, in future, this model can be expanded and specified increasing the scope of the research.

1. Arcand J., Berkes E., Panizza U. (2012). Too Much Finance? IMF Working Paper, WP/12/161.

2. Bayraktar N. (2014). Measuring relative development level of stock markets: Capacity and effort of countries. Borsa Istabul Review, 14(2): 74-95.

3. Beck T. (2012). Financial possibility frontier: understanding structural and policy gaps in financial systems. Jointly organized by The International Monetary Fund, jointly with the World Bank in Washington D.C.

4. Beck T., Feyen E. (2013). Benchmarking financial systems: Introducing the financial possibility frontier. WB Working Paper Series, 6615

5. Beck T., Feyen E.H.B., Ize A., Moizeszowicz F., (2008). Benchmarking financial development. World Bank, Policy Research Working Paper 4638.

6. Brown L., Osborne S. P. (2013). Risk And Innovation. Retrieved from: http://www.paulallen.ca/documents/2015/08/brown-land-sp-osborne-risk-and-innovation-towards-a-framework-for-risk-governance-in-public-services 2013.pdf

7. CEIC (2018). Market capitalization statistics. Retreived from: https://www.ceicdata.com/en/contact_us.htm

8. Clayton T., Dal Borgo M., Haskel J. (2009). An Innovation Index Based on Knowledge Capital Investment: Definition and Results for the UK Market Sector. Retrieved from: http://ftp.iza.org/dp4021.pdf

9. De la Torre A., Feyen E., Ize A. (2013). Financial development: structure and dynamics. World Bank Economic Review, 27: 514-541.

10. European Commision. European Innovation Scoreboard (2017). Retrieved from: https://www.rvo.nl/sites/defaultfiles/2017/06/European_Innovation_Scoreboard_2017.pdf

11. European Commision. Innovation Statistics. Retrieved from: http://ec.europa.eu/growth/industry/innovation/factsfigures/scoreboards_It 
12. Eurostat database. Statistics retrieved from https:/lec.europa.eu/eurostat/data/database

13. Glor E. D. (2003). Innovation Traps: Risks and Challenges in Thinking About Innovation. The Innovation Journal. 8(2): 118.

14. Gujarati D.N. (2009) Basic Econometrics. Tata McGraw-Hill Education, New Delhi.

15. Harrington H. J., Voehl F. (2015) The Innovation Tools Handbook. Retrieved from: https://books.google.lt/books?hl=|t\&|r=\&id=8e4bDAAAQBAJ\&oi=fnd\&pg=PA335\&dq=S-

Curve+model\&ots=cK6_GsI7sw\&sig=ahmfKKImHZ-_4C-0gddRjwa-fNI\&redir_esc=y\#v=onepage\&q=S-Curve\%20model\&f=false

16. Hinloopen J. (2003). Inovation Performace Across Europe. Economics of Innovation and New Technology, 12(2):145-161.

17. Hisrich R. D., Kearney C. (2014). Managing Innovation and Entrepreneurship. SAGE Publications.

18. Kirstukas J., Rakštys R., Serva E., Vaznonis B. (2013) Inovaciju ir techniniu pokyčiu ekonomika. [Economics of Development and Changes $\urcorner$ ].

19. Krušinskas R., Benetytè R., (2016). Investiciju i technologines inovacijas naudos ir rizikos vertinimas inovaciju indeksu palyginimo kontekste. [Assessment Of Benefits And Risk Of The Investment In Technological Innovations In The Context Of Innovation Indices Comparison]. Science and Studies of Accounting and Finance: Problems and Perspectives, 10(1).

20. Levine R. (1997). Financial development and economic growth. Journal of Economic Literature, 35: 688-726.

21. Levine R., Zervos S. (1996). Stock market development and long-run growth. The World Bank Economic Review, 10: 323 339

22. Lowrey W., (2011). Institutionalism, news organizations and innovation. Journalism Studies, 12(1): 64-79.

23. Lynch D., (1996). Measuring financial sector development: a study of selected Asia-Pacific countries. Developing Economies, 34: 3-33

24. Malinoski M., Perry G. S. (2000). How Do I Measure „Innovation“ ?!?

25. Melnikas B., Jakubavičius A., Strazdas R. (2000). Inovacijos. [Innovation]. Retrieved from: http://www.inovacijos.It/inopagalba/cms/62lt.pdf

26. Preda A. M., Crisan D. A., Stanica J. L. (2014). The impact of ict on innovation performance in europe. Case of Romania Retrieved from: http://search.proquest.com/openview/0b605850bf9b70fea31ecd0d4b195bee/1?pq-origsite=gscholar\&cbl=1216366

27. Torres-Reyna O. (2007). Panel data analysis. Fixed and random effects. Princeton University. Retrieved from: http://www.princeton.edu/ otorres/Panel101.pdf (žiūrèta 2017 m. gruodžio $21 \mathrm{~d}$.).

28. Tufano (2002). Financial Innovation. In Handbook of the Economics and Finance.

29. Vaškelaitis V. (2010). Finansinès inovacijos: turinys, prieštaringumas, rizikos valdymas. [Financial innovation, discrepancy and risk management] Retrieved from: http://www.su.It/bylos/mokslo_leidiniai/ekonomika/10 01 17/vaskelaitis.pd

30. Wang J., Medianu D., Whalley J. (2011). The Contribution Of China, India And Brazil To Narrowing North-South Differences In Gdp/Capita, World Trade Shares, And Market Capitalization. NBER Working Paper, 17681.

31. Miškinis A., Sakalauskaitè R., (2014). Tiesioginiu užsienio investiciju Lietuvoje pritraukimo veiksniai. [Main factors to attract foreign direct investment]. Prieiga per internetą: https://www.ceeol.com/search/article-detail?id=160193 (žiūrèta 2017 m. birželio 2 d.).

32. Morkvènas, R. (2010). Organizacijos žiniu potencialo vertinimas. Daktaro disertacija. [Assessment of potential of organizational knowledge. Doctoral thesis]. Vilnius: Technika.

33. Tvaronavičienè Manuela; Rafael Žaneta. Vertybiniu popieriu rinka Lietuvoje: aktyvumo ivertinimas bei pagrindiniu veiksniu analizè. [Securities market in Lithuanina: activity assessment and analysis of key factors]. Verslas: teorija ir praktika. Vilnius: Technika. ISSN 1648-0627. T. 4, nr. 1 (2004), p. 10-21

34. Bedford D.A.D., Carlson, P., Wagner, C. and Ramanathan, J., (2015). Architecture and design of a knowledge index for cities. In Academic Conferences and Publishing International (ACPI), Proceedings of the 7th European Conference on Intellectual Capital (ECIC 2015). Cartagena, Spain, 9-10 April 2015.

35. World Fintech Report (2017). Fintech Index. Retrieved from: https://www.marsdd.com/wpcontent/uploads/2015/02/CapGemini-World-FinTech-Report-2017.pdf

36. Wintermeyer L. (2016). Capital markets: innovation and the FinTech landscape. Retrieved from:: http://www.ey.com/Publication/vwLUAssets/EY-capital-markets-innovation-and-the-finTech-landscape/\$FILE/EY-capital-marketsinnovation-and-the-fintech-landscape.pdf

37. Cherchye L., et al. (2008). Creating composite indicators with DEA and robustness analysis: the case of the technology achievement index. Journal of the Operational Research Society, 59(2), 239-251.

38. Wonglimpiyarat J. (2011). Innovation Index and Innovative Capacity of Nations. Futures, 42(3):247-253.

39. Lopez-Claros, A., Yasmina, M., (2009). The Innovation Capacity Index: Factors, Policies, Institutions Driving Country Innovations. Palgrave Macmillian.

A. Паскевічус, Ph.D., просресор, Вільнюський університет (Вільнюс, Литва);

Г. Келіоуотіте-Станіуленієнє, Ph.D., доцент, Вільнюський університет (Вільнюс, Литва).

Оцінка впливу FinTech-інновацій на розвиток ринку капіталу країн Центральної та Східної Європи

Незважаючи на те, що ряд дослідників, які вивчають інновації в иілому, вказують на ризикований характер фінансових інновацій та необхідність більш детального вивчення їх впливу, емпіричні дослідження, присвячені 
A. Paskevicius, G. Keliuotyte-Staniuleniene. The Evaluation of the Impact of Financial Technologies Innovations on Ceecs Capital Markets

оцінюванню впливу FinTech-інновацій на розвиток ринків капіталу, є поодинокими. Для країн Центральної та Східної Європи достовірні емпіричні докази, що однозначно підтверджують висновок щодо позитивного або негативного впливу FinTech-інновацій на розвиток ринків капіталу, в теперішній час взагалі відсутні. Для вирішення цієї проблеми авторами здійснено системний аналіз наукової літератури з теми дослідження та використано статистичні методи, зокрема порівняльний динамічний аналіз, моделі панельних даних (з постійними, фіксованими та випадковими ефектами) та інші. Представлена в статmі панельна модель впливу FinTech-інновацій на ринки капіталу побудована на основі аналізу даних 9 країн Центральної та Східної Європи за дванадиятирічний період (2006-2017рр.). Запропонована авторами модель пояснює майже чотири п'ятих змін на ринку капіталу, виражених через рівень його капіталізації. Панельні моделі з постійними, фріксованими та змінними ефектами засвідчили негативний статистично значущий вплив інтегрального інноваційного індексу, який відображає рівень та межі впливу FinTech-інновацій на розвиток ринків капіталу в країнах Центральної Європи (інші релевантні макроекономічні змінні приймалися в розрахунках як контрольні). Панельна модель також показала, що статистично значущий позитивний вплив на розвиток ринку капіталу у країнах Центральної та Східної Європи був спричинений прогнозним зростанням ВВП, інфляциєю та іншими змінними, що характеризують капітальні інвестиції. З іншого боку, прямі іноземні інвестиції, безробіття, процентна ставка, державний борг, дефріцит державного бюджету не мають статистично значущого впливу на розвиток ринків капіталу у досліджуваних країнах Центральної та Східної Європи. Представлена модель характеризується досить високими показниками надійності та детермінації, тому може бути використана для подальшої оцінки та проектування впливу FinTесh-інновацій та інших параметрів на розвиток ринків капіталу.

Ключові слова: інновації, фінансові технології, капітал, ринок, капіталізація, оцінка впливу. 